\title{
THE ROLE OF THE LEADER IN THE INSTITUTIONAL COMMUNICATION PROCESS IN TRNC PRIMARY SCHOOLS
}

\author{
O PAPEL DO LÍDER NO PROCESSO DE COMUNICAÇÃO INSTITUCIONAL NAS ESCOLAS PRIMÁRIAS \\ DE TRNC
}

\section{EL PAPEL DEL LÍDER EN EL PROCESO DE COMUNICACIÓN INSTITUCIONAL EN LAS ESCUELAS PRIMARIAS DE TRNC}

\begin{abstract}
The general purpose of this research is the examination of the role of the leader in the institutional communication process in TRNC primary schools. While conducting the research, principals and deputy principals, who are administrators in primary schools, were accepted as leaders in schools. At this point, it has been tried to determine how teachers perceive corporate communication in TRNC primary schools and whether their administrators show a leading role in terms of communication skills. Among the most important results of the research; Primary school teachers with a bachelor's degree had a more positive attitude towards the communication skills of their administrators than primary school teachers with a master's degree. Most of the teachers (69.4\%) participating in our study stated that the most important feature that a leader should have is "effective communication skills".
\end{abstract}

Keywords: communication, education leader, leadership.

Resumen: O objetivo geral desta pesquisa é o exame do papel do líder no processo de comunicação institucional nas escolas primárias TRNC. Durante a realização da pesquisa, diretores e vicediretores, que são administradores nas escolas primárias, foram aceitos como líderes nas escolas. Neste ponto, tentou-se determinar como os professores percebem a comunicação corporativa nas escolas primárias TRNC e se seus administradores mostram um papel de liderança em termos de habilidades de comunicação. Entre os resultados mais importantes da pesquisa; Os professores

\footnotetext{
${ }^{1}$ Near East University. N.Cyprus, Nicosia.

${ }^{2}$ Alayköy Primary School. N.Cyprus, Nicosia.
} 
primários com diploma de bacharel tiveram uma atitude mais positiva em relação às habilidades de comunicação de seus administradores do que os professores primários com mestrado. A maioria dos professores $(69,4 \%)$ participantes do nosso estudo afirmou que a característica mais importante que um líder deve ter é a "capacidade de comunicação eficaz".

Palabras clave: comunicação, líder educacional, liderança.

Resumo: El propósito general de esta investigación es el examen del papel del líder en el proceso de comunicación institucional en las escuelas primarias de la TRNC. Al realizar la investigación, los directores y subdirectores, que son administradores en las escuelas primarias, fueron aceptados como líderes en las escuelas. En este punto, se ha intentado determinar cómo los docentes perciben la comunicación corporativa en las escuelas primarias de TRNC y si sus administradores muestran un rol protagónico en cuanto a habilidades comunicativas. Entre los resultados más importantes de la investigación; Los profesores de primaria con una licenciatura tenían una actitud más positiva hacia las habilidades comunicativas de sus administradores que los profesores de primaria con una maestría. La mayoría de los profesores $(69,4 \%)$ que participaron en nuestro estudio afirmaron que la característica más importante que debe tener un líder es la "capacidad de comunicación eficaz".

Palavras-chave: comunicación, líder educativo, liderazgo.

\section{INTRODUCTION}

Communication is very important to all of us. We need to be in constant communication with people in order to convey our thoughts and wishes to the people we face and find solutions to our problems. It is not possible for us to live our lives alone in the world we live in. For this reason, importance should be given to communication in order to both understand and express ourselves and to establish positive relationships with people. Different definitions have been made by many researchers about communication. Hallgarten (2000, p. 11) observed that rather than promote communication between home and school, information policies served primarily to increase the flow of information from school to parent. Moreover, this information may not always be what parents actually want.(Hugles \& Greenhough, 2006, p. 475)

Eskiyörük (2015, p. 50) on the other hand; It is likened to a partnership, association and socialization. As it can be understood from here, it seems that communication is really a very strong bond that connects people. When people who come into communication work in a certain institution, they have to act together in order to achieve their goals. Institutional Communication emerges with this mutual interaction.

For Solmaz (2004, p. 25) institutional communication is defined as the communication carried out within the framework of certain rules in order to ensure the unity, flow of information, motivation, integration, evaluation, decision-making and control between the units that make up the institution.

The significant aim of educational institutions is to raise self-developed, educated and successful individuals. Accordingly, the fact that input and output are human in educational environments increases the importance of communication one more time. Studies (Flora, 2000, p.290), (Castells, 2007, p. 29) have stated that the most important feature that distinguishes a school from others is the cultural structure of the school rather than its physical structure. The most 
important feature that determines the cultural structure of a school stems from the communication between the administrators, teachers and students in that school (Celep, 2000, p. 82).

The general purpose of this research is the examination of the role of the leader in the institutional communication process in TRNC primary schools. While conducting the research, principals and deputy principals, who are administrators in primary schools, were accepted as leaders in schools. At this point, it has been tried to determine how teachers perceive corporate communication in TRNC primary schools and whether their administrators show a leading role in terms of communication skills.

\section{Sub-problems of the study:}

Within the framework of the general purpose stated above, the research included the following sub-objectives;

1- Do the views of the teachers differ about communicating to their the administrators in TRNC primary schools in terms of;

a) the variable of gender?

b) the education level?

c) the branch?

d) the tenure of office in the school they are in?

2- What is the notification status the teachers working in primary schools; their managers?

3- According to the teachers working in primary schools; information about the school through which channel does it reach them?

4- Does the relevant information reach them quickly on time to the teachers working in primary schools?

5- What is the most important feature of leader according to the teachers in primary schools?

\section{Literature Review}

In order to establish a healthy communication in an educational environment, it is very important for all employees to be in contact with each other, to trust each other, to know and respect each other, and most importantly, not to hate each other. When a correct communication is established between people, relations that seem to be disconnected enter into a certain order and this situation provides a conscious balance between institutional and individual goals (Çağlayan, 2002, p. 64).

In an educational environment, a fair approach by school administrators towards their teachers will improve their teachers' self-confidence as well as ensure that they stay away from unethical behaviors. Teachers' creativity in school and classroom work will increase as school administrators prefer such a positive communication method with their teachers (Altun, 2003, p. 8)

It is not an easy situation to be a manager in an educational environment. It is even a stressful job because of the decisions that need to be made at the most crucial moments. Managers can face many different problems. The most important problems experienced in the educational 
environment are the problems that occur between teachers or employees. In order to eliminate these difficulties, managers can be realized if they know the working environment well, follow the relationships between employees and fully understand their personalities. Knowing these relations well by the administrators is very important for the successful management of that educational environment (Özalp, 2003, p.83).

According to Çelik (2011, p.90), the expectations from a training manager are as follows:

- To be able to solve the problems they encounter,

- To have an effective communication ability,

- Being smart, hardworking and knowledgeable,

- Have a social personality,

- Give importance to their physical appearance,

- Confidence in themselves,

- Being responsible,

- Being successful in human relations,

- To be able to make effective decisions and,

- To have the ability to take decisions in a calm manner in a crisis situation.

As a result we can say that; Those who are administrators in an educational environment are the lifeblood of their school. Starting from the problems related to the school, solving communication problems, conducting the educational environment provided in the school in the best way, enabling parents to come together in line with the needs of the school, and most importantly, ensuring that all these components can act in coordination as a whole in order for the school to reach the goals and objectives easily. Managers have a great role to play.

Schools; They are educational institutions where education and training services are provided to students, an effective education environment is provided for a healthy life, and students from different cultures gather together to develop themselves and acquire positive behavior.

Each educational institution has education staff responsible for its healthy functioning. The most important steps that can be taken to increase the success of an educational institution is to ensure and manage all the members of this institution to work actively and in harmony (Zel, 2002, p. 40).

In order to achieve this and to increase the quality of education provided by the school, two important factors are mentioned. These are the leadership behaviors exhibited by the administrators in that school and the motivation source provided on the teachers and employees in the school. The leadership style exhibited by the administrators in schools creates positive or negative effects on the employees working in the school and these effects are directly reflected in the success of the school (Esmer, 2020, p.233). 


\section{METHODOLOGY}

While conducting the research, principals and deputy principals, who are administrators in primary schools, were accepted as leaders in schools. At this point, it was tried to be determined from the eyes of teachers, how the institutional communication is perceived by teachers in TRNC primary schools and whether their administrators show a leading role in terms of communication skills. Quantitative method was used to achieve the aims of the study. Analyzing the responses given by the teachers and evaluating the extent to which the administrators in their schools fulfilled their leadership roles, it was aimed to determine whether the participants made a significant difference according to the variables of gender, education level, branch, tenure at the school and the district where the school is connected. It was determined that the most suitable model to be applied for this purpose should be the relational scanning model, which is one of the general scanning models.

\section{Population and Sample:}

The target group for data collection is permanent teachers working in primary schools. Stratified sampling, which is one of the random sampling methods, will be used in the selection of teachers.

Stratified sampling aims to represent the subgroups in the population in proportion to their weight here. Drawing units from sub-universes is performed using simple unbiased sampling (Büyüköztürk et.al, 2012, p.36).

In the light of the above information, the universe of the research consists of 1135 teachers working as permanent staff in the official primary schools affiliated to the Turkish Republic of Northern Cyprus (TRNC) Ministry of National Education and Culture (MEKB) in the 2019-2020 academic year.

The sample group of the study consists of 160 teachers working in the first, second, third, fourth and fifth grades of the official primary schools affiliated to the Ministry of National Education and Culture of the Turkish Republic of Northern Cyprus in the 2019-2020 academic year. While determining the sample group, one of the random sampling methods, the stratified sampling method was used.

During the preparation of the sample, the permanent teachers in public schools in six districts (Nicosia, Famagusta, Girne, Güzelyurt, İskele and Lefke) in TRNC were reached depending on the representation rates in the universe and the necessary data were collected through stratified sampling. In this context, 50 teachers (31.3\%) working in Nicosia district, 44 teachers working in Famagusta district (27.5\%), 33 teachers working in Girne district (20.6\%), 12 teachers working in Güzelyurt district (7\%), 5), 15 teachers (9.4\%) working in Iskele district and 6 teachers (3.8\%) working in Lefke district were reached and the sample of the study was determined to be 160 teachers.

\section{Data Collection Process and Tools:}

Primary school teachers; Quantitative data were collected showing the communication skills they see in their managers. Questionnaire form of Ercan Aktan was used as data collection method. 
The data was collected on the internet via Google form starting from 25/5/2020 until 25/7/2020. The collection period lasted two months.

The target audience for data collection is permanent primary school teachers working in official primary schools affiliated to MEKB in TRNC. Stratified sampling was used in the selection of teachers. In addition, the strata were determined on district basis and teachers working in different districts of Cyprus were reached. They were contacted and included in the study. Participants were not given any incentives for their participation. Participant information forms were distributed to the participants over the Google form from the internet through the e-mail addresses I received from the Ministry. The consent of the participants was received when I first communicated about the subject.

\section{Findings}

Findings Regarding the Second Sub-Problem of the Study:

Table 1: T-Test Results for the Gender Variable

\begin{tabular}{|l|l|l|l|l|l|l|}
\hline Group & N & Mean & ss & t & Df & p \\
\hline Female & $\mathbf{8 6}$ & 3,98 &, 759 &, 647 & 158 &, 519 \\
\hline Male & 74 & 3,90 &, 862 & & & \\
\hline
\end{tabular}

Table: Elaborated by the authors

The findings about the gender variable are that the participants 'managers' views on communication skills do not differ according to the gender variable $(p=, 519)$.

Table 2: T-Test Results for Education Variable

\begin{tabular}{|l|l|l|l|l|l|l|}
\hline Group & N & Mean & ss & t & Df & p \\
\hline Undergrad. & 122 & 4,05 &, 795 & 3,12 & 157 &, 002 \\
\hline Grad. & 37 & 3,59 &, 762 & & & \\
\hline
\end{tabular}

Table: Elaborated by the authors

The findings obtained for the education variable are that the participants' views of their managers about communication skills differ according to the education variable $(p=, 002)$. 
Table 3: T-test Results for the Branch Variable

\begin{tabular}{|l|l|l|l|l|l|l|}
\hline Group & N & Mean & ss & t & Df & p \\
\hline $\begin{array}{l}\text { Classroom } \\
\text { Teacher }\end{array}$ & 93 & 3,87 &, 769 & $-1,46$ & 158 &, 145 \\
\hline $\begin{array}{l}\text { Branch } \\
\text { Teacher }\end{array}$ & 67 & 4,05 &, 850 & & & \\
\hline
\end{tabular}

Table: Elaborated by the authors

The findings for the branch variable are in the direction that the opinions of the managers of the participants about the communication skills do not differ according to the branch variable $(p=$, 145).

Table 4: Descriptive Statistics Regarding the Term of Office at the Same School

\begin{tabular}{|l|l|l|l|}
\hline Group & N & Mean & ss \\
\hline $\mathbf{1 - 4}$ & 50 & 4,04 &, 781 \\
\hline $\mathbf{5 - 8}$ & 34 & 3,91 &, 830 \\
\hline $\mathbf{9 - 1 2}$ & 30 & 3,90 &, 803 \\
\hline $\mathbf{1 3 - 1 6}$ & 21 & 4,19 &, 679 \\
\hline $\mathbf{1 7}$ and above & 25 & 3,68 &, 900 \\
\hline Total & $\mathbf{1 6 0}$ & $\mathbf{3 , 9 5}$ & $\mathbf{8 0 7}$ \\
\hline
\end{tabular}

Table: Elaborated by the authors

The most positive opinion (4.19) about the participants' views on the communication skills of the managers came from the participants who worked for 13-16 years. The most negative opinion (3.68) came from participants who worked for 17 years or more.

Table 5: ANOVA Results regarding the tenure of office

\begin{tabular}{|l|l|l|l|l|l|}
\hline & Sum of Squares & sd & Mean of squares & F & p \\
\hline Between Groups & 3,567 & 4 &, 892 & 1,382 &, 243 \\
\hline Within Groups & 100,033 & 155 &, 645 & & \\
\hline Total & $\mathbf{1 0 3 , 6 0 0}$ & $\mathbf{1 5 9}$ & & & \\
\hline
\end{tabular}

Table: Elaborated by the authors

The findings showed that the participants' views on the communication skills of their managers did not differ according to the tenure variable $(p=, 243)$. 
Findings Regarding the Second Sub-Problem of the Study:

What is the status of their administrators to inform them according to teachers working in primary schools?

Table 6: Descriptive Statistics Regarding Information Receiving

\begin{tabular}{|l|r|r|}
\hline Information Receiving & F & \% \\
\hline Yes & 145 & 90,6 \\
\hline No & 15 & 9,4 \\
\hline Total & $\mathbf{1 6 0}$ & $\mathbf{1 0 0}$ \\
\hline
\end{tabular}

Table: Elaborated by the authors

The majority of the participants (\%90.6) stated that their managers informed them about the events and decisions experienced.

Findings Regarding the Third Sub-Problem of the Study:

According to the teachers who work in primary schools, through which channel do information about the school reach them?

Table 7: Information Regarding Channels Through Which Information About School Is Accessed

\begin{tabular}{|l|l|l|}
\hline Info Channel & f & $\%$ \\
\hline Meeting & 125 & 78,1 \\
\hline Face to face & 18 & 11,3 \\
\hline Official notice & 11 & 6,9 \\
\hline Gossiping & 6 & 3,8 \\
\hline Total & $\mathbf{1 6 0}$ & $\mathbf{1 0 0}$ \\
\hline
\end{tabular}

Table: Elaborated by the authors.

The majority of the participants (\%78.1) stated that they received information about the school through meetings.

\section{Findings Regarding the Fourth Sub-Problem of the Study:}

Does the relevant information reach them quickly on time to the teachers working in primary schools? 
Table 8a: Information on Timely Access to School Information

\begin{tabular}{|l|c|c|}
\hline Timely Access of the info & f & \% \\
\hline Always & 46 & 28,8 \\
\hline Mostly & 74 & 18,8 \\
\hline Sometimes & 30 & 5,6 \\
\hline Rarely & 9 &, 6 \\
\hline Never & 1 & 100 \\
\hline Total & 160 & 160 \\
\hline
\end{tabular}

Table: Elaborated by the authors

Participants mostly answered "most of the time" (\%46.3) that information about the school reaches them quickly.

Table 8b: Information on Timely Notification Status of All Teachers

\begin{tabular}{|l|r|r|}
\hline All teachers timely notification & F & \% \\
\hline Always & 44,5 \\
\hline Mostly & 51,3 \\
\hline Sometimes & 28 & 17,5 \\
\hline Rarely & 6 & 3,8 \\
\hline Never & 0 &, 0 \\
\hline Total & 160 & $\mathbf{1 0 0}$ \\
\hline
\end{tabular}

Table: Elaborated by the authors

Participants mostly answered "most of the time" (\%51.3) to inform all teachers on time.

Findings Regarding the Fifth Sub-Problem of the Study

What is the most important feature of leader according to the teachers in primary schools? 
Table 9: Information on the Proficiency Level of Social Purpose Communication

\begin{tabular}{|l|c|r|}
\hline Proficiency Level of Social Purpose Communication & F & \% \\
\hline Yes & 91 & 56,9 \\
\hline No & 69 & 43,1 \\
\hline Total & 160 & $\mathbf{1 0 0}$ \\
\hline
\end{tabular}

Table: Elaborated by the authors

Most of the participants (\%56.9) stated that social communication is sufficient.

\section{Discussion}

Considering the findings obtained as a result of the research, it was seen that the opinions of the participants about their managers' communication skills in terms of gender variable did not differ. In the studies conducted by Kurt (2015, p. 79), Wood (2011, p. 67) and Yılmaz (2015, p. 91) on the communication skills of the administrators in preschool education institutions, it was revealed that teachers' opinions did not differ in terms of the communication skills of their administrators according to the gender variable, and it was determined that the results found were in parallel with this study. Doğan et al. (2016) found similar findings in his research on teachers 'perceptions of managers' communication skills, and it was determined that no differentiation occurred depending on the gender variable of the participants. As a result of these results, it can be said that the gender differences of teachers in educational institutions do not make any difference in terms of the opinions of administrators regarding communication skills. The fact that there is no difference in teachers 'evaluations of the communication of their administrators due to gender differences within educational institutions can be explained that there is no negative environment within the school that will affect teachers' opinions on this issue due to gender differences. It can be said that these conclusions have been reached due to the fact that both educational institutions and administrators working in the public sector in the TRNC are close to gender equality. Delamont $(2012$, p. 75$)$ states that gender roles are always desired and expected to be kept in the background in school environments.

Tomaç (2009, p. 63), in his research on how preschool teachers perceive the communication skills of their administrators, found that associate degree graduates evaluate the communication skills of their managers more positively than undergraduate graduates and undergraduate graduates compared to graduate graduates. As a result of these researches, when the research conducted on the teachers of our country is evaluated, it can be concluded that as the education level of the teachers increases, the communication skills they expect from their administrators also increase.

In the study conducted with teachers, it was concluded that the opinions of the participants about the communication skills of their administrators did not differ depending on the branch variable. Kösterelioğlu and Argon (2010), in their research on how teachers perceive their 
administrators' effectiveness in communication skills, concluded that the branch variable did not make any difference in the opinions of the participants and it was determined that there were parallel results with this study. Çınar $(2010$, p. 8), in his research on the effectiveness of the managers in the communication process from the eyes of the educators, found that the opinions differ depending on the branch variable. Çınar made the assumption that the reason for this change is that the subject teachers sometimes have more free time in the curriculum in the school than other teachers and that they can have such an opinion by communicating with the principal more at these times. As a result of these results, it can be said that school administrators approach all teachers in the same way in the direction of communication and similar views emerge when the evaluation is made by looking at the variable of branch and classroom teachers in our country's primary schools.

\section{CONCLUSION}

In this study, research was conducted to determine the role of the leader in the corporate communication process in TRNC primary schools. In order to obtain the necessary results regarding the research, primary school teachers were reached in six major districts where TRNC primary schools are located. According to the teachers working in primary schools, the results obtained regarding the state of informing them by their administrators are as follows: Most of the teachers working in primary schools (90.6\%) stated that their administrators informed them about the events and decisions taken, while some teachers (9.4\%) stated that they were not informed about the incident and the decisions taken. At this point, the majority of the teachers stated that they were informed about the events by their administrators, which enabled us to reach the server where the information flow in the school was progressing positively. According to the teachers who work in primary schools, the results obtained regarding the channel through which information about the school reach them are as follows: In the light of the information provided by the teachers working in primary schools, they stated that the information about the school was conveyed to them mostly (78.1\%) through the meetings held. On the other hand, some teachers (11.3\%) stated that this information was given face to face, while a very small group of teachers stated that it was given by official writing $(6.9 \%)$ or by whispering (3.8\%). As a result of the research, we can say that teachers are generally informed through the meetings held. This gave us the impression that the information in the school was conveyed to the teachers in an unity. According to the teachers working in primary schools, the results obtained regarding whether social communication is done at a sufficient level or not are as follows: While some of the primary school teachers who participated in our study (56.9\%) agreed that social communication took place, some of the teachers $(43.1 \%)$ stated that social communication was not realized at a sufficient level. When a general evaluation was made in the light of this information, it was seen that although most of the teachers stated that social communication was carried out at a sufficient level outside of school, a considerable number of teachers made the opposite evaluation. Accordingly, it can be argued that social communication between teachers takes place, but it should be spread to all teachers by increasing it. 


\section{RECOMMENDATIONS}

This research was carried out with primary school teachers working in official primary schools affiliated to the Ministry of Education. In the future, similar studies can be applied to primary school teachers working in private primary schools. In this study, the data obtained from the questionnaire were obtained through the answers given by the teachers. The data to be obtained from a similar research in the future can be obtained with the opinions of the managers. Thus, a comparison of the findings obtained from both studies can be made. The role of the teacher in the corporate communication process in TRNC primary schools can be evaluated in the further research. Considering the current covid-19 pandemic process, it is recommended to conduct new research on whether online meetings between administrators and teachers increase in-school communication.

\section{REFERENCES}

ALTUN, S. A. (2003). Eğitim yönetimi ve değerler. Değerler Eğitim Dergisi, Ankara, v. 1, n. 1, s. 7-17,

Aktan, E. (2007). Kurumsal Iletişim Sürecinde Liderin Rolü. Yayımlanmamış Yüksek Lisans Tezi, Selçuk Üniversitesi Sosyal Bilimler Enstitüsü.

BÜYÜKÖZTÜRK, ş. (2012). ve diğerleri. Bilimsel araştırma yöntemleri 11. Ed. Ankara: Pegem Akademi.

ÇAĞLAYAN, A. (2002). Ilköğretimlerde eğitimde yönetim, yönetimde kalite. 1. Ed. Ankara: Bilge Yayıncılık.

CELEP, C. (2000). Eğitimde örgütsel adanma ve öğretmenler. 1. Ed. Ankara: Anı Yayıncılık.

CASTELLS, M. (2007). Communication, power and counter-power in the network society. International journel of communication, U.S, v. 1, n. 1, s. 29.

ÇELIK, V. (2011). Yönetim ve liderlik kuramları. V. Çelik içinde, Türk eğitim sistemi ve okul yönetimi. 1. Ed. Ankara: Pegem A Yayıncılık.

ÇıNAR, O. (2010). Okul müdürlerinin iletişim sürecindeki etkililiği. Dumlupınar Üniversitesi Sosyal Bilimler Dergisi, v. 26.

KÖSTERELIOĞLU, M. A. (2010). Okul yöneticilerinin iletişim sürecindeki etkililiğine .ilişkin öğretmen algıları. Ahi Evran Üniversitesi Eğitim Fakültesi Dergisi, Bolu, v. 11, n. 1, s. 1-17.

DELAMONT, S. (2012). Sex roles and the school. 71. Ed. New York: Routledge.

Dias, A. F. (2020). Trans* escrevivências as a pedagogical power. Journal of Research and Knowledge Spreading, 1(1), 1-17.

Dias, A. F., Cardoso, H. de M., Santos, A. L. dos, Menezes, C. A. A., \& Rios, P. P. S. (2017). Schooling and subversions of gender. Revista Tempos e Espaços em Educação, 10(22), 83-92.

ESKIYÖRÜK, D. (2015). Örgütsel Illetişim. 1. Ed. İstanbul: Cinius Yayınları. 
ESMER, Y. (2020). Okul yöneticilerinin liderlik yönelimlerinin belirlenmesi: Sinop ilii Örneği. Türkiye Sosyal Araştırmalar Dergisi, Ankara, v. 24, n. 1, s. 231-241.

Fullagar, S. (2019). A physical cultural studies perspective on physical (in)activity and health inequalities: the biopolitics of body practices and embodied movement. Revista Tempos $e$ Espaços em Educação, 12(28), 63-76.

HALLGARTEN, J. (2000). Parents Exist, OK!?: Issues and visions for parent-school relations. 1. Ed. London: Institute for Public Policy Research.

HUGLES, M.; GREENHOUGH, P. (2006). Boxes, bags and videotape: enhancing home-school communication through knowledge exchange activities. Educational Review, U.S, v. 58, n. 4, s. 471-487.

KÖSTERELIOĞLU, M. A. (2015). Okul yöneticilerinin iletişim sürecindeki etkililiğine ilişkin öğretmen algıları. Ahi Evran Üniversitesi Eğitim Fakültesi Dergisi, Bolu, v. 11, n. 1, s. 1-17, 2010.

KURT, S. (2015). Okul öncesi eğitim kurumu yöneticilerinin iletişim becerileri. SP. $108 \mathrm{f}$. Yayımlanmamış Yüksek Lisans Tezi - Çanakkale Onsekiz Mart Üniversitesi Eğitim Bilimleri Enstitüsü, Çanakkale

ÖZKALP, E. (2003). Örgütsel Davranış. 1. Ed. Eskişehir: Anadolu Üniversitesi Yayınları.

SEGRIN, C.; FLORA, J. (2004). Poor social skills are a vulnerability factor in the development of psychosocial problems. Human communication research, London, v. 26, n. 3, s. 489-514.

Silva, T. O. \& Rios, P. P. (2020). Gender, sexual diversity and field education: "in rural communities many people do not understand and treat it as a disease. Journal of Research and Knowledge Spreading, 1(1), 1-12.

SOLMAZ, B. (2005). Kurumsal söylenti ve dedikodu. 1. Ed. Konya: Tablet Yayınları.

TOMAÇ, S. (2009). Anaokulu öğretmenlerinin iletişim becerileri açısından yöneticileri algılamaları. SP. 2009. 108 f. Yayımlanmamış Yüksek Lisans Tezi - Maltepe Üniversitesi Sosyal Bilimler Enstitüsü, İstanbul.

WOOD, J, T. (2011). Communication Mosaics: An Introduction to the Field of Communication. 6. Ed. Boston: Wadsworth Pub,

YILMAZ, H. (2015). O Okul yöneticilerinin kişiler arası iletişim becerilerinin okul öncesi öğretmenlerinin görüşleri açısından incelenmesi. SP. 2015. 132 f. Doktora Tezi - Selçuk Üniversitesi Eğitim Bilimleri Enstitüsü, Konya.

ZEL, U. (2002). İş arenasında kadın yöneticilerin algılanması ve kraliçe arı sendromu. Amme Idaresi Dergisi, Istanbul, v. 35, n. 2, s. 39-48. 


\section{ABOUT THE AUTHORS}

\section{Mert Baştaş}

Associate Professor, Department of Social Sciences Education, Near East University. N.Cyprus, Nicosia.

Email: mert.bastas@neu.edu.tr

ORCID: https://orcid.org/0000-0001-5149-5451

\section{Hüseyin Aktunç}

Teacher, Alayköy Primary School. N. Cyprus, Nicosia.

Email: huseyinaktunc@hotmail.com

ORCID: https://orcid.org/0000-0001-5907-632

Received on: 08-26-2020

Approved on: 11-05-2020

Published on: 12-11-2020 